DOI 10.22460/infinity.v6i2.p157-168

\title{
ANALYSIS OF DIDACTICAL CONTRACTS ON TEACHING MATHEMATICS: A DESIGN EXPERIMENT ON A LESSON OF NEGATIVE INTEGERS OPERATIONS
}

\author{
Nyiayu Fahriza Fuadiah ${ }^{1}$, Didi Suryadi ${ }^{2}$, Turmudi ${ }^{3}$ \\ ${ }^{1}$ Universitas PGRI Palembang, Jl. Jend A. Yani Lorong Gotong Royong No. 9/10, \\ Palembang, North Sumatera, Indonesia \\ ${ }^{2,3}$ Universitas Pendidikan Indonesia, Jl. Setiabudi No.229, Bandung, West Java, Indonesia \\ ${ }^{1}$ nyiayufahriza@ univprgri-palembang.ac.id, ${ }^{2}$ ddsuryadi1@gmail.com, ${ }^{3}$ turmudi@upi.edu
}

Received: July 11, 2017 ; Accepted: September 11, 2017

\begin{abstract}
This paper presents the analysis of teaching of Math that took place in the classroom to identify the characteristics of didactical contracts that occur as part of a didactical situation. The design experiment was conducted on 31 seventh grade students and a mathematics teacher on negative integer operations lessons. The researchers analyzed the ongoing learning, how the didactical situation stages evolve in the teacher-student interaction that allows the formation of new knowledge or concepts in the student and how the teacher organizes the responsibility for achieving the learning objectives. The Analysis showed that students, at an early stage, can perform negative integers operations by utilizing the basic concepts they get in primary school. This concept can bridge into a new knowledge that identifies the properties of integer count operations and builds power of mind on problem-solving.
\end{abstract}

Keywords: Didactical Contract, Didactical Situation, Negative Integers Operations.

\begin{abstract}
Abstrak
Artikel ini menganalisis pengajaran matematika yang berlangsung di dalam kelas dalam mengindentifikasi karakteristik kontrak didaktis yang terjadi sebagai bagian dari situasi didaktis. Disain eksperimen dilakukan terhadap 31 siswa kelas 7 dan seorang guru matematika pada pelajaran operasi bilangan bulat negatif. Peneliti melakukan analisis terhadap pembelajaran yang berlangsung, bagaimana tahap-tahap situasi didaktis berkembang dalam interaksi guru-siswa yang memungkinkan terbentuknya pengetahuan baru atau konsep pada siswa dan bagaimana guru mengorganisir tanggung jawab untuk mencapai tujuan pembelajaran. Analisis menunjukkan bahwa siswa, pada tahap awal, dapat melakukan operasi hitung bilangan bulat negatif dengan memanfaatkan konsep dasar yang mereka dapatkan di sekolah dasar. Konsep ini dapat menjembatani menuju pengetahuan yang baru yaitu mengidentifikasi sifat-sifat operasi hitung bilangan bulat dan membangun daya pikir pada pemecahan masalah.
\end{abstract}

Kata Kunci: Kontrak Didaktis, Situasi Didaktis, Operasi Bilangan Bulat Negatif.

How to Cite: Fuadiah, N. F., Suryadi, D., \& Turmudi (2017). Analysis of Didactical Contracts on Teaching Mathematics: A Design Experiment on a Lesson of Negative Integers Operations. Infinity, 6 (2), 157-168. doi:10.22460/infinity.v6i2.p157-168 


\section{INTRODUCTION}

Mathematics learning is a process of interaction between teachers and students that involve the development of thinking patterns and processing logic in a learning environment that deliberately created by teachers. Good interaction between teacher and student describes the learning process can be done well. The interaction among teachers and students is a social activity that does not escape the constraints that can come from both. Brousseau (2002) refers to the obstacles of the theories conveyed by Bachelard in 1938 and Piaget in 1975 on "errors", that mistakes and failures play a role that is not simple. This type of mistake is unpredictable, called obstacles. This error is a part of the acquisition of knowledge. It is also the underlying theory of the didactic situation, namely obstacles. The analysis of this constraining problem becomes important to be expressed in order to better optimize the construction of new knowledge processes and reduce the obstacles that occur.

Analysis of learning problems during this time is more emphasized on students while the analysis of how the teachers teach has not received more attention. Both these analyzes can synergize in designing the learning in accordance with the conditions and needs of students. Analysis of teaching can improve teacher strategy in future teaching, priority material emphasis, more reproduction of time for a concept, the type of task that must be given to students, anticipate the questions and responses that may arise, and teacher's control to know the extent to which the learning objectives have been achieved. These things are teacher's responsibility to plan effective learning.

We can say that the teacher's job is not easy. The greatest role of math teachers in the formation of new knowledge on the students is 'to turn on' mathematics through creating situations in which they are planning to teach (Sarrazy \& Novotna, 2013). Teaching means to create conditions in which something new may emerge. This creation is central to the teacher's work: to create problems and solving the problems. Teachers and students have their respective responsibilities that cannot be exchanged. This is what didactics of mathematics calls the didactical contract.

\section{Didactical contract}

The concept of the didactical contract is undoubtedly one of the best known concepts of didactics of mathematics (Sarrazy \& Novotna, 2013). Didactical contract was described by Brousseau (2002) as a set of rules that define the responsibilities of teachers and students in an interaction of teaching and learning. Further, didactical contract has meaning that 'teachers are required to teach and students must learn', teachers assign tasks and students perform these tasks. Didactical contract is also defined as the rules of the game and strategy in a didactic situation. It is a justification for the situation presented by the teacher. Situational changes allow for the modification of contracts in which new situations occur (Brousseau, 2002).

Didactical contract is divided into two categories: devolution contract that teachers organize student's mathematical activities whose respond to the activities, and institutionalization contract that students propose the outcomes they get and the teachers provide directions that match the knowledge reference (Hersant \& Perrin-Glorian, 2005; Brousseau, Sarrazy \& Novotna, 2014). The process of devolution and institutionalization then was introduced to relate the dimensions of acculturation and adaptation of educational endeavor even though they were under the responsibility of the teacher. According to Artigue, Haspekian \& CorblinLenfant (2014) the devolution process is the process of negotiating with teachers through a 
didactical contract which temporarily allows for the transfer of responsibilities regarding the teacher's knowledge goals to the students. Through devolution, teachers make their students accept math responsibility to solve problems without ignoring didactic goals, and maintaining them, creating conditions that should be a means of learning through adaptation. Through institutionalization, teachers help students to connect their contextual knowledge has been built in an adidactical situation in accordance with the targets of knowledge to be achieved and thus the teacher re-assigns decontextualization and transforms into "savoirs" (Brousseau (2002) distinguished between "knowledge" and "knowings" Knowledge is the "connaissances" of individual cognitive awakening, while knowings are "savoirs", the cognitive construct that appears in the social aspect)

Furthermore, the idea of didactical contract has been developed to differentiate some types of contracts. The level of didactic contract structure proposed by Hersant and Perrin-Glorian (2005) were: macro-contract, meso-contract, and micro-contract. Macro-contract primarily relate to the purpose of teaching, meso-contract with the realization of an activity, such as exercise resolution, while the micro-contract corresponds to an activity focused on the unit of mathematical content, eg concrete questions in practice. Chevallard and Barquero (Arias \& Araya, 2009) introduced different interactions characterizing the practice of adidactical potential in a potential adidactical contract. This type of contract offers new responsibilities to the student, an important responsibility to identify. This form of accountabilities required students to explain their suggestions and contribute to rebuilding the cognitive path that leads them to the learning objectives. Teachers do not need to answer all questions and they should contribute to ask questions to students. They must also develop the skills to argue, in properly communicating ideas and knowing about learning in other ways (metacognition). An important aspect set in the potential adidactical contract is that teachers (with students) make clear rules in applying these skills in other contexts.

\section{Students' difficulties on negative number}

Integer is the first number faced by students that require reasoning with numbers less than zero which cannot be modeled in real (Stephan \& Akyuz, 2012). In mathematics education, students' difficulties in negative numbers are often found (Vlassis, 2008; Bellamy, 2015). Some articles detailed outlines the struggle of mathematician with integers, especially with the meaning of number less than zero (Hefendehl-Hebeker, 1991; Gallardo, 2002).

Bishop, Lisa, Philipp, Whitacre, Schappelle, \& Lewis (2014) conducted a series of studies to identify cognitive obstacles about students' perceptions in negative numbers. Results of the research shown that students have problems in understanding negative numbers because of they assume that result of addition cannot be smaller and result of subtraction cannot be greater. This opinion is based on their perception that number is a real so that no number which is "less than nothing" or below zero (Bishop, et. al, 2014). A study conducted by Lamb, Bishop, Philipp, Schappelle, Whitacre, \& Lewis (2012) found that only about a quarter of high school students interviewed were correct in identifying - (-4) as greater than -4. Furthermore, they did not realize that they have enough information to determine which is greater than $-\mathrm{x}$ or $\mathrm{x}$.

Seng (2012) also revealed that students' difficulties in arithmetic operations involving negative numbers become one of the major obstacles in understanding the concept of algebra. The result of the error analysis that he studied on grade 7 students showed that students had difficulties in integer manipulating, which is the basic skill in solving algebraic expressions. 
This error came about because students applied the rules in arithmetic incorrectly that they have learned, students more likely use procedural approaches in manipulating negative integers.

\section{Research questions and objectives}

Based on the described descriptions and theoretical framework, the researchers focused on the activities undertaken by the teacher, how the teacher managed the class by creating anticipation of the student's responses, and how the learning trajectory passed by the students. All of these questions will lead to how the characteristics of the didactical contract in the learning of the counting operation of negative numbers. This research was expected to answer the question how didactical contract phenomenon in a learning process. Analysis of this teaching is expected to be used as a benchmark teacher in teaching to improve the quality of learning next.

\section{METHOD}

\section{Participant}

Arithmetic operations of negative integer in this research is a part of the Hypothetical Learning Trajectory (HLT) that was designed by researchers in Negative Integers material. This study is an implementation of HLT in phase of design experiment after pilot experiment. Implementation of the design was carried out in 31 students in one of the 7th grade in a junior high school in Palembang (11-12 years old) and a mathematics teacher as a model teacher (5 years teaching experience) in the odd semester of the year academic 2016/2017. The first researcher took a role as an observer to observed the learning activities directly and record all the didactical activities within the classroom that can be observed.

\section{Data collection and analysis}

Three cameras were used to record all learning activities. Students and teachers activities then were transferred into a continuing conversation transcript through the coding process to identify the characteristics of the didactical contract. All data were analyzed descriptively qualitatively to get a comprehensive picture of the learning process, how the teacher manages the learning, and how the student process finds new ways in addition and negative integer reduction operations. The learning process was described based on the stage of didactical situation.

\section{RESULTS AND DISCUSSION}

The learning was done in two stages, 1) simple problem solving on integers, and 2) integer count operation. The whole learning was done in four learning activities (see Table 1). The learning objective is the student can use the counting operation and determine the result exactly in solving the problem (macro-contract).

Table 1. Learning scheme of operations of negative integers

\begin{tabular}{lll}
\hline \multicolumn{1}{c}{ Learning Phase } & \multicolumn{1}{c}{ Goal } & \multicolumn{1}{c}{ Learning Activity } \\
\hline $\begin{array}{l}\text { Simple problem } \\
\text { solving }\end{array}$ & $\begin{array}{l}\text { Know that in the operation of } \\
\text { a number can produce } \\
\text { positive or negative numbers }\end{array}$ & $\begin{array}{l}\text { Simple addition and subtraction of } \\
\text { integers }\end{array}$ \\
$\begin{array}{l}\text { The used of addition and subtraction } \\
\text { for simple problem solving. }\end{array}$ \\
\hline
\end{tabular}




\begin{tabular}{|c|c|c|}
\hline Learning Phase & Goal & Learning Activity \\
\hline \multirow{2}{*}{$\begin{array}{l}\text { Operations of } \\
\text { integers }\end{array}$} & \multirow{2}{*}{$\begin{array}{l}\text { Can perfom the addition and } \\
\text { subtraction involving negative } \\
\text { integers }\end{array}$} & The concept of operations with tools \\
\hline & & $\begin{array}{l}\text { The concept of operations without } \\
\text { tools }\end{array}$ \\
\hline
\end{tabular}

\section{Activity 1: Simple addition and subtraction of integers}

This section was the initial stage of learning in which the didactical contract is implicitly emphasized on the "call the concept back" on the student, especially the addition and subtraction that students have learned when they were in elementary school, including integer operations, and student knowledge that the results of the operation of numbers can be either positive or negative. Looking back at the extent students mastered this concept will greatly help teachers create a didactical situation for the next learning at a higher level. This process is a devolution contract whereby the teacher assigned responsibility to the student to solve the problem as a learning tool through the adaptation process. One of the problems and answers of Student 1 can be seen in Figure 1.

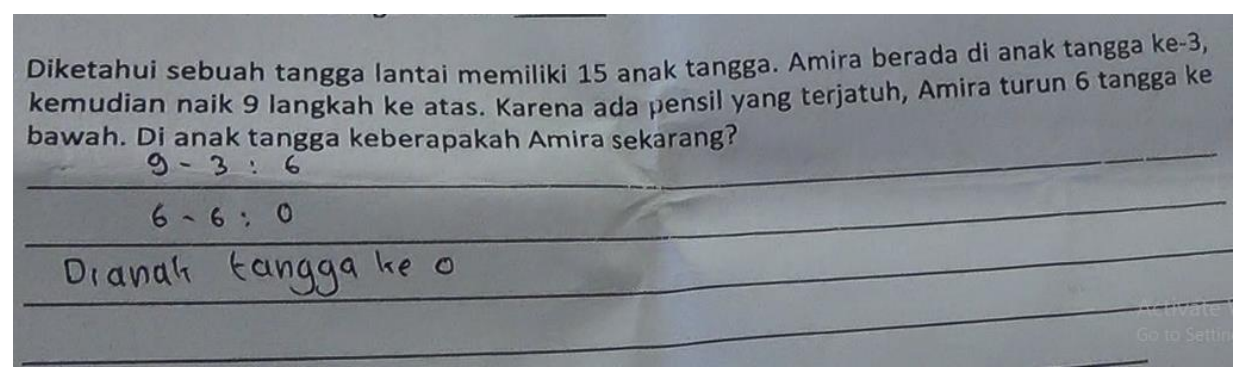

Figure 1. The answer of Student 1

Translate: A ladder has 15 steps. Amira is on the 3rd step, then up 9 steps up. Because there was a pencil that fell, Amira down 6 flights of stairs down. On what steps is Amira now?

The mistake at Student 1 was the operation that is applied to answer the problem about the ladder. It should be Amira positions before she was down is $9+3$. The answers like this also happen to some other students. The purpose of the teacher that students can make appropriate counting operations for this simple problem is failed so that teacher needed to straighten out the concept of students. As an anticipation of these student errors, teacher directed students using vertical numbers to represent the staircase then provide some questions that lead the students. The use of number line as a model has known in general by the students. Didactical contract is the process of negotiation that allows the transfer of knowledge goals from the teacher to the students (Artigue, Haspekian, \& Corblin-Lenfant, 2014).

\section{Activity 2: Use of operation of integer to solve the problem.}

This activity offered the use of integer operations in solving the problems. The situation that will built was how students can apply the concept of counting operations in solving problems in everyday life with the construction of correct thinking. This conditioning is very important to improve students' thinking structures at a later stage with appropriate instructional design. Here are the problems given to students: 
Mr. Andi and Mr. Cahyo have savings of Rp. 250.000, - and Rp. 150.000, -. Besides, they also have a loan, Mr. Andi Rp. 175.000, - and Mr. Cahyo Rp. 50.000, -. How is the way for Mr. Andi's balance to be Rp. $350.000,-$ ?

Here's the answer of one student (Student 2),

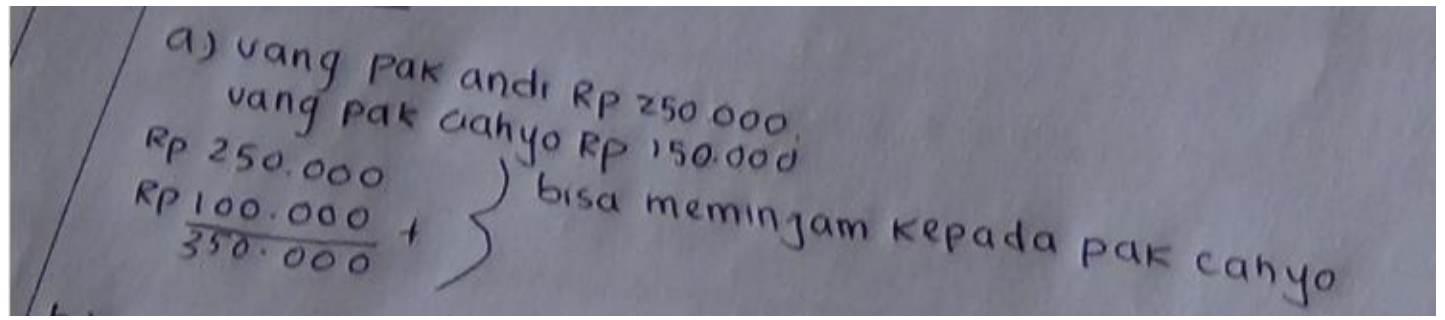

Figure 2. The answer of Student 2

Translate:

Mr. Andi's money Rp. 250.000,-

Mr. Cahyo's money Rp. 150.000,-

Rp. 250.000,- + Rp. 100.000,- = Rp 350.000,- (Mr. Andi must add Rp. 100.000,- to be Rp. 350.000,-). He can borrow it to Mr. Cahyo.

Student 2's answer show that he did not take into account the loan as one of Mr. Andi's balance factors. This loan should be subtraction first from savings so that the remaining balance was final.

The process of filing a problem to construct new knowledge (which will later be used to solve a problem) sometimes does not guarantee a didactical situation under a fully undertaken didactical contract (Hersant \& Perrin-Glorian, 2005). This is what will be the basis when the responses given by the student show that the student has not been able to perform the operation exactly, then the teacher action is create a new didactical situation in accordance with the needs of the students. In this case a meso-contract agreement was adopted through a new situation, ie the teacher provided help by elaborating the problem so that it is easily solved by the students. In the ordinary learning process, an adidactical situation is sometimes rare, but some situations have the potential to occur (adidactical potential). It is said to be 'potential' because teachers can get involved managing the situation, evaluating students' answers without waiting for students to react to feedback from the milieu.

Brousseau (2002) explained that in a didactical situation, if the teacher feels a failure in the learning process, the student does not meet the expected learning goals, so the teacher is said not to meet student expectations implicitly. Students will be 'complain' because they cannot solve the problem given by the teacher. This situation leads to a conflict in the teacher, why this is happen. Conflict experienced by teachers, negotiation, and the search for a new contract will continue the didactic relationship through a new didactical situation. In this case the teacher assumed that previous learning and new conditions bring the student to new learning possibilities. This is done by the teacher after, which is designing learning calculation operations so that students can understand the concept of counting operations and not just memorize the procedure. This learning design will carried out in the next learning activity that is the counting operation of negative integers. 


\section{Activity 3: The concept of addition and subtraction involving negative number with tools}

In this learning activity, students were not faced with the usual problems but learning was directed entirely by the teacher at an early stage with the aim of establishing new knowledge about the operation of a negative integer (micro-contract). The concept of operation was built using the tools in the form of a jar containing green and red candies, each of which amounts to 25 pieces. Students were divided into 4 groups based on the seating row. Each group got a jar of candies. These candies illustrate the positive and negative numbers with the illustrations shown in Figure 4.

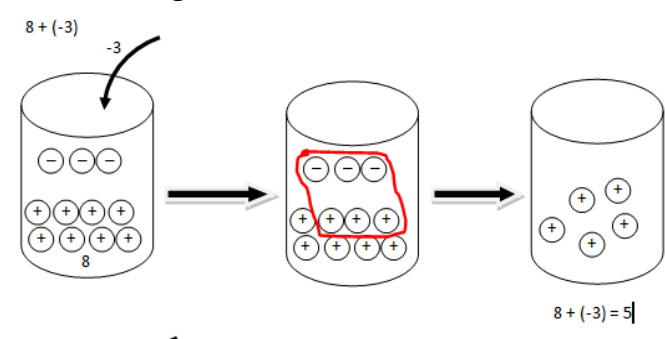

a. Addition
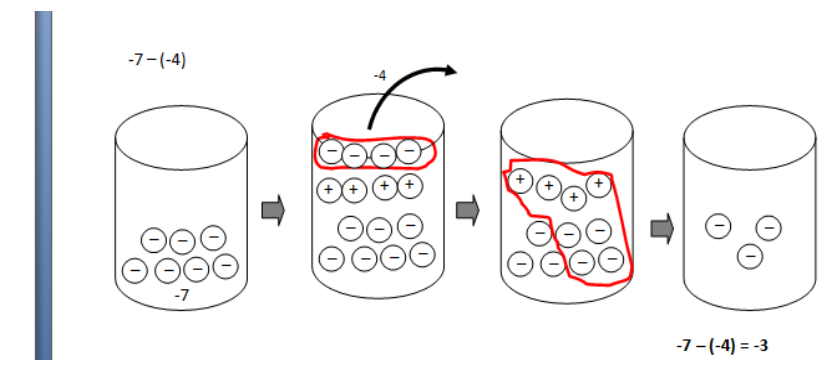

b. Subtraction

Figure 3. Operations of addition and subtraction with a jar and candies

Implicitly, students were introduced to the concept of inverse in addition through one red candy and one blue candy equal to zero. Using the concept of summation that summing is a "batch" of two quantities, students will later realize that the sum can also be negative. The concept of subtraction that students understand as "take away" was still used here. In the construction of other concepts built on this activity, the teacher does not simply inform that "negative is negative as positive" but how students find the concept that $a-(-b)$ will be equal to $a+b$.

Students in Group 2 perform a operation for 4 - (-8) by including 4 blue candies (representing positive 4) and 8 red candies (representing negative 8), then issuing 8 red candies (subtraction). Once calculated results obtained are 4 blue candies or equal to 4 . Response as already predicted by previous teachers.

Teacher

Students

Teacher

Surya

Teacher

Students

Teacher

Akbar

Teacher

Students

Teacher

Surya

Teacher

Students
: What are our previous agreements for reduction operations?

: Mmm ... (weak voice)

: All right. Have you put 4 positive candies into the jar? How about negative $8 ?$

: Eight red candies, Ma'am.

: That's it? Is the same 4 with 4 minus 0 ?

: It is the same, Ma'am

: Is 8 blue candies with 8 red candies same with zero?

: Same thing Mom, meaning $8+(-8)=0$

: Right. Now, there are 4 with 4 blue candies then added 8 blue candies and 8 red candies?

It's the same, Ma'am

: Why?

: Because 8 blue candies and 8 red candies are equal to zero.

: So what are you going to do?

: (put 8 blue candies and 8 red candies into the jar then take out 8 red candies and count the rest) 
Didactical contract can change when students were unable to perform subtraction of negative numbers immediately so that teacher needed to guide students by demonstrating their procedures over and over through some examples (meso-contract). This needed to be done so that the mathematical concepts that are obtained not just memorize it. Teacher had been monitoring student work in the group to ensure that learning objectives are well achieved. Observations conducted by the researchers showed students did not experience obstacles in performing the operation in this way. The most important part of this stage is that students can perform count operations for larger numbers that may not be represented with concrete objects or number line. With the concept that has been obtained, students are expected to perform abstraction on operations without tools.

\section{Activity 4: Arithmetic operation without tools}

The concept of arithmetic operations that had been studied was very useful in determining the results of operations for multi-digit numbers. Jar and candies were still used as abstract models at the beginning of the calculation, but then gradually no longer use the model directly even though the rules were still used. This method can be easily understood by students compared to using a number line or other tools. Teacher assistances were still needed in every stage of mathematical abstraction so that students can actually calculate with the right concept. At the beginning of this activity students are asked to perform operations on $23-45$. Besides the students can count it, the teacher also wanted to implant the concept indirectly that $23-45$ is the nature of $23+(-45)$. Seeing many students who have not given the right answer, the teacher took the initiative to explain the procedure used procedure of subtraction that they have learn (Figure 4).

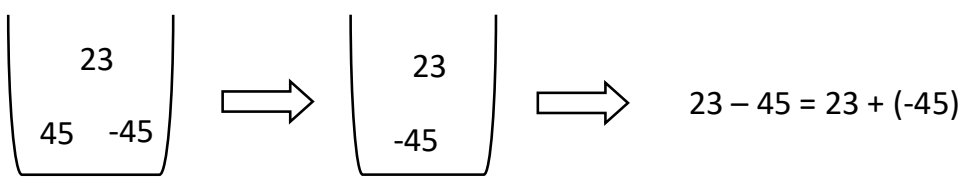

So that,

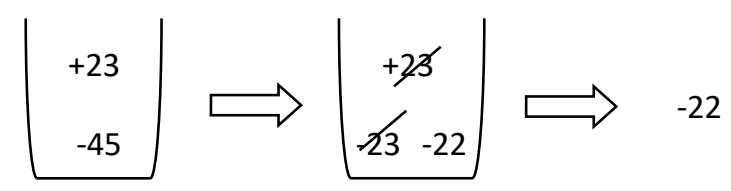

Figure 4. The operation's procedure for $23-45$

To fill the theorems and strategies on the board is one way to show teachers' understanding of mathematical material (Kinslenko, 2005). The teachers then gave some questions as assignments for the students. This stage was a validation situation, i.e. students convey their ideas and teachers play a role to bridge their knowledge to achieve the intended knowledge (Brousseau, 2002). That was in line with what was stated by Kinslenko (2005) that teachers start with what is known and end with the knowledge of mathematics through the construction process. Students were required to solve the problem and they make clear and complete explanations of the theory and any way that has been used to solve the problem. Almost all students experienced constraints in determining the operating results of $23+(-32)$ and $15-$ (-33). Repeated work is required to get the correct answer.

Teacher : :How are you doing? Where are you up to?

Indra $\quad$ : We're still having trouble in 15 - (-33), Ma'am.

Teacher $\quad:$ Let's try to remember the previous way, using the candies. How to subtract?

Fadhil : Use candies, Maam 


$\begin{array}{ll}\text { Teacher } & : \text { Well with this. If less }-33 \text { what will we do? } \\ \text { Students } & : \text { Mmm ... (weak voice) } \\ \text { Teacher } & : \text { You must write first } 33 \text { and what? } \\ \text { Bimo } & : \text { Negative } 33 \text { (write the numbers }+33 \text { and }-33 \text { above the number 15) } \\ \text { Teacher } & : \text { Then, how much should be taken away? } \\ \text { Students } & : \text { Negative } 33 . \\ \text { Teacher } & : \text { Now what number is left? Let's try to count on that! }\end{array}$

The errors that occur precisely the starting point in the process of constructing knowledge. The teacher's responsibility in this process is to ensure that students use the right strategy. Of course requires patience from both of, teacher and students.

Arias and Araya (2009) described a different type of interaction between students and studentteacher whose characteristics illustrate the adidactical potential practice in a potential adidactical contract. According to Arias and Araya further, the teachers not answer all the questions and they have to contribute to questioning among students. Also, they must develop skills as to argue, to communicate precisely the ideas, to know about other ways of learning (metacognition). In this case, it was necessary for teacher intervention to modify the milieu so that students can improve their understanding of a concept. This type of contract offers new responsibilities to the student, an important responsibility to identify. This form of responsibility requires students to explain their suggestions and contribute to rebuilding the cognitive path that leads them to the learning objectives through the questioning that builds the intended knowledge to the students.

The properties of the counting operation is a concept that students get then after the concept of counting operations. Knowledge of these traits should not be obtained by memorizing as it has been so far. Observations made by the researcher showed that teacher tend to provide information or formulas of operations. Consequently there was much misconception on the students because students simply apply the rote without knowing the concept (Fuadiah, Suryadi \& Turmudi, 2017). To embed this concept to students, students are given several operations with the same result then students compare between an operations with other operations. Thus the student know the properties of the operation, for example, $\mathrm{a}-\mathrm{b}$ will give the same result as $a+(-b)$ or $a-(-b)$ will equal the result with $a+b$. Noteworthy in this study is the student's emphasis on the concept of base-ten number and inverse addition. This concept is indispensable for students to count multiplex numbers, especially negative numbers.

Mastery in arithmetic operations will affect students in solving problems. The study showed that students who can determine the mathematical model in solving the problem can find obstacles in performing the arithmetic operation (Hunges, 1986). At the next level of learning, such as algebra, students can algebraically model correctly but incorrectly in their countdown operations (Seng, 2012). Based on students' difficulties, Vlassis (2004) suggest that the minus sign plays a major role in the development of understanding and using negative numbers.

In theory of didactical situation, to improve students' autonomy, teachers should be more likely to have a lesson-learned intervention (Brousseau, 2002; Manno, 2006; Perrin-Glorian, 2008; Ruthven, Laborde, Leach, \& Tiberghien, 2009; Artigue, Haspekian, \& Corblin-Lenfant, 2014). This situation, argued by Laborde and Perrin-Glorian (2005), adidactical situations are designed to minimize the involvement of the teacher in the learning process. However, in the practice of learning that occurs, teacher assistance is needed as a teacher anticipation of the 
response of students who developed during the learning such as providing questions that can lead students to an understanding.

Student responses that indicate the learning objectives that have not been achieved will result the didactical contract was broken. Therefore teachers anticipated by creating new situations that involve the role of teachers larger. Those were expressed by Hersant and Perrin-Glorian (2005) that the process of filing a problem to construct new knowledge (which would later be used to solve a problem) sometimes does not guarantee a didactic situation under a fully undertaken didactical contract. In this activity, as an act of student response, the teacher provided a re-explanation of the meaning of "take away" of the subtraction. Teacher's action is to give an example of an easier operation than ever so that the students can understand more easily by recalling previously learned concepts. In a didactical situation where students are given the opportunity to solve problems without teacher intervention, teacher assistance is still needed as a part of didactical contract. Conflict experienced by teachers, negotiation, and the search for a new contract will continue the didactic relationship through a new didactical situation (Brousseau, 2002). This new situation is then built by the teacher when the student has not been able to perform the counting operation through the correct concept, so that the teacher needs to redirect the possibility of the operation algorithm that students can do.

\section{CONCLUSION}

The analysis of the teaching and learning process on this study that has been going on there are some didactical situational changes in anticipation of the broken didactical contract, namely: 1) creating a new didactical situation to support students' ability in performing the arithmetic operation because the teacher's expectation that the student can perform the counting operation is constrained on negative number, 2) teacher assistance as one of the implementation of didactical contract can be done through the questions that lead can bridge the students to understanding the concept so that not only know the procedure only. Action and feedback through a strategy will enable the building of a new knowledge. Based on the identification of the characteristics of the didactical contract in this study, there are two types of dominant didactical contract, namely 1) Mayeustic Socratic Contract, occurring in the early stages of the learning process of adaptation where the teacher does not fully dominate but helps the child's learning process through the provision of key questions that exploring the experience and early knowledge of the students to elicit relevance to the concepts to be studied; and 2) Potential Adidactical Contract, in student learning describes the question and does not wait for the answer. Also, students are called to answer other students' questions, so teachers are not the only ones who have the right answers. Students should explain their suggestions and contribute to rebuilding the cognitive way that leads them to a result (Arias \& Araya, 2009). This type of contract occurs in institutionalization where there is awareness among students about a concept that has become a self-sustaining student (savoirs). Analysis of the implementation of the design of learning needs to be done continuously by analyzing the demands and needs of students are very diverse. The diversity needs to be accommodated in learning, because the act of uniformity of students with diverse reality is not wise and proportional.

\section{REFERENCES}

Arias, F., \& Araya, A. (2009). Analysis of the didactical contracts in 10th grade math classes. Quaderni di Ricerca in Didattica (Matematica), 4(19), 155-163. 
Artigue, M., Haspekian, M., \& Corblin-Lenfant, A. (2014). Introduction to the theory of didactical situations (TDS). In Networking of theories as a research practice in mathematics education (pp. 47-65). Springer International Publishing.

Bellamy, A. (2015). A critical analysis of teaching and learning negative numbers. Philosophy of Mathematics Education Journal, 29.

Bishop, J.P., Lisa, L.L, Philipp, R.A., Whitacre, I., Schappelle, B., and Lewis, M.L. (2014). Obstacles and affordances for integer reasoning: an analysis of children's thinking and the history of mathematics. Journal for Research in Mathematics Education, 45(1), 19-61. http://dx.doi.org/10.5951/jresematheduc.45.1.0019

Brousseau, G. (2002). Theory of Didactical Situation in Mathematics. USA: Kluwer Academic Pulishers.

Brousseau, G., Sarrazy, B. \& Novotna, J. (2014). Didactic contract in mathematical education. In Lerman (Ed.), Encylopedia of Mathematics Education (pp. 153 - 159). Dordrecht: Springer.

Fuadiah, N. F., Suryadi, D., \& Turmudi, T. (2017). Some difficulties in understanding negative numbers faced by students: A qualitative study applied at secondary schools in Indonesia. International Education Studies, $10 \quad$ (1), 24-38. http://dx.doi.org/10.5539/ies.v10n1p24

Gallardo, A. (2002). The extension of the natural-number domain to the integers in the transition from arithmetic to algebra. Educational Studies in Mathematics, 49(2), 171192. https://doi.org/10.1023/A:1016210906658

Hefendehl-Hebeker, L. (1991). Negative numbers: obstacles in their evolution from intuitive to intellectual contructs. For the Learning of Mathematics,11(1), 26 - 32. http://www.jstor.org/stable/40248003

Hersant, M., \& Perrin-Glorian, M. J. (2005). Characterization of an ordinary teaching practice with the help of the theory of didactic situations. Educational Studies in Mathematics, 59 (1-3), 113-151. http://dx.doi.org/10.1007/s10649-005-2183-z

Hughes, M. (1986). Children and Number, Difficulties in Learning Mathematics. United Kindom: Blackwell Publishing.

Kinslenko, K (2005). Student's beliefs about mathematics from the perspective of the theory of didactical situations. In C Winslow (ED.), Didactic of mathematics-the French way (pp. 83-96). Center For Naturfagenes Didaktis University of Copenhagen.

Lamb, L.L., Bishop, J.P., Philipp, R.A., Schappelle, B.P., Whitacre, I., \& Lewis, M. (2012). Developing symbol sense for the minus sign. Mathematics Teaching in the Middle School, 18(1), 5-9. http://dx.doi.org/10.5951/mathteacmiddscho.18.1.0005

Laborde, C. \& Perrin-Glorian, M.J. (2005). Introduction teaching situation as object of research: empirical studies within theoretical perspective. Educational Studies in Mathemathics, 59 (1-3),1-12. http://dx.doi.org/10.1007/s10649-005-5761-1

Manno, G. (2006). Embodiment and a-didactical situation in the teaching-learning of the perpendicular straight lines concept. Doctoral Thesis. Departement of Didactic Mathematics Comenius University Bratislava 
Perrin-Glorian, M. J. (2008). From producing optimal teaching to analysing usual classroom situations development of a fundamental concept in the theory of didactic situations: the notion of milieu. Accepted from https://www.unige.ch/math/EnsMath/Rome2008/WG5/Papers/PERRIN.pdf

Ruthven, K., Laborde, C., Leach, J., \& Tiberghien, A. (2009). Design tools in didactical research: instrumenting the epistemological and cognitive sspects of the design of teaching sequences. Educational Researcher, 38 (5), 329-342. https://doi.org/10.3102/0013189X09338513

Sarrazy, B., \& Novotna', J. (2013). Didactical contract and responsiveness to didactical contract: a theoretical framework for enquiry into students' creativity in mathematics. ZDM Mathematics Education, 45:281-293. http://dx.doi.org/10.1007/s11858-013-04964.

Seng, L. K. (2012). An error analysis of form 2 (grade7) students in simplifying algebraic expression: a descriptive study. Electronic Journal of Research in Education Psy. 8 (1),139-162.

Stephan, M., \& Akyuz,, D. (2012). A proposed instructional theory for integer addition and subtraction. Journal for Research in Mathematics Education, 43 (4), 428-464. http://dx.doi.org/10.5951/jresematheduc.43.4.0428

Vlassis, J. (2004). Making sense of the minus sign or becoming flexible in 'negativity'. Learning and Instruction, 469-484. http://dx.doi.org/10.1016/j.learninstruc.2004.06.012

Vlassis, J. (2008). The role of mathematical simbols in the development of number conceptualization: The case of the minus sign. Philosophical Psychology, 21(4), 555570. http://dx.doi.org/10.1080/09515080802285552 